\title{
Expression of vascular endothelial growth factor (VEGF) receptors in rat corpus luteum: regulation by oestradiol during mid-pregnancy
}

\author{
N. Sugino, S. Kashida, S. Takiguchi, A. Karube-Harada and H. Kato \\ Department of Obstetrics and Gynecology, Yamaguchi University School of Medicine, \\ Minamikogushi 1-1-1, Ube 755-8505, Japan
}

\begin{abstract}
The aim of this study was to investigate the expression of vascular endothelial growth factor (VEGF) receptors, the fms-like tyrosine kinase (flt-1) and kinase insert domaincontaining region (KDR), in corpora lutea obtained at different stages of the oestrous cycle and during pregnancy in rats. Immunohistochemistry revealed that both flt-1 and KDR were localized in luteal cells in addition to vascular endothelial cells, and that the intensity of staining was stronger in pregnant rats than in cyclic rats. Rats undergoing hypophysectomy-hysterectomy on day 12 of pregnancy were treated with oestradiol until day 15 of pregnancy to determine whether oestradiol is involved in expression of flt-1 and KDR mRNA in the corpus luteum during mid-pregnancy. The flt-1 and KDR mRNA contents
\end{abstract}

in the corpus luteum were decreased significantly by hypophysectomy-hysterectomy, and these decreases recovered significantly after oestradiol treatment. Changes in the mass of the corpus luteum and serum progesterone concentrations paralleled the changes in expression of flt-1 and KDR mRNA. Developmental studies indicated that flt-1 and KDR mRNA contents in the corpus luteum were constant until day 15 of pregnancy but decreased significantly on day 21 of pregnancy. In conclusion, both flt-1 and KDR were expressed in luteal cells in addition to vascular endothelial cells, and expression was upregulated by oestradiol during mid-pregnancy. flt- 1 and KDR may play a role in development of the corpus luteum and in production of progesterone during mid-pregnancy in rats.

\section{Introduction}

Angiogenesis plays an important role in the development of the corpus luteum and in maintenance of luteal function (Tamura and Greenwald, 1987; Gibori, 1993; Ferrara et al., 1998; Fraser et al., 2000; Kashida et al., 2001). During midpregnancy in rats, the corpus luteum increases rapidly in size, mainly due to hypertrophy of luteal cells, and the number of endothelial cells in the corpus luteum and luteal blood flow also increases (Bruce et al., 1984; Tamura and Greenwald, 1987; Gibori, 1993). High vascularization appears to be necessary to provide luteal cells with the large amounts of cholesterol needed for progesterone synthesis and for the delivery of progesterone to the circulation. Vascular endothelial growth factor (VEGF) is a protein that has the potential to play a dynamic role in the regulation of vascular endothelial growth, angiogenesis and vascular permeability (Ferrara and Davis-Smyth, 1997). VEGF is expressed in rat corpora lutea (Phillps et al., 1990; Koos, 1995; Kashida et al., 2001) and is essential for luteal angiogenesis leading to development of the corpus luteum (Ferrara et al., 1998; Fraser et al., 2000; Kashida et al., 2001). Oestradiol is necessary for development of the corpus luteum and maintenance of luteal function during

Email: obgyn@po.cc.yamaguchi-u.ac.jp mid-pregnancy in rats (Tamura and Greenwald, 1987; Gibori, 1993; Kashida et al., 2001). Oestradiol is also responsible for the increase in angiogenesis observed in the corpus luteum during mid-pregnancy in rats (Tamura and Greenwald, 1987; Kashida et al., 2001). Kashida et al. (2001) demonstrated that VEGF in the corpus luteum was upregulated by oestradiol and that the angiogenic effect of oestradiol was mediated by VEGF in the corpus luteum during mid-pregnancy in rats.

VEGF has two receptors, the fms-like tyrosine kinase (flt-1) and kinase insert domain-containing region (KDR), both of which are found generally on vascular endothelial cells. Both flt-1 and KDR are expressed in luteal cells as well as in vascular endothelial cells in human corpora lutea (Otani et al., 1999; Sugino et al., 2000a). In addition, VEGF receptors are expressed in a variety of non-endothelial cells (Ergün et al., 1997; Wen et al., 1998; Krüssel et al., 1999; Möller et al., 2001) and are functional in these cells (Barleon et al., 1996; Clauss et al., 1996; Ahmed et al., 1997; Brown et al., 1997; Athanassiades et al., 1998). However, little is known about the expression of VEGF receptors in rat corpora lutea. As luteal VEGF is upregulated by oestradiol and contributes to progesterone production (Kashida et al., 2001), it would be interesting to determine whether VEGF receptors can also be upregulated by oestradiol. The aim of the present study was to examine the expression of VEGF receptors, flt- 1 and KDR in rat corpora lutea and to investigate the 
regulation of VEGF receptors by oestradiol during midpregnancy.

\section{Materials and Methods}

\section{Animals}

Sprague-Dawley rats (Japan SLC Inc., Hamamatsu), weighing 220-270 g, were housed at $24^{\circ} \mathrm{C}$ under controlled conditions (lights on from 05:00 h to 19:00 h) with free access to standard rat chow and water. Vaginal smears were obtained daily and only rats showing at least two consecutive 4 day oestrous cycles were used. Pro-oestrous rats were housed with males overnight and day 1 of pregnancy was defined as the day on which spermatozoa were found throughout a vaginal smear. The experimental protocol was reviewed and approved by the Committee for the Ethics on Animal Experiment in Yamaguchi University School of Medicine under the Law (No. 105) and Notification (No. 6) of the Government.

\section{Immunohistochemistry}

Immunohistochemistry was performed on ovaries from different stages of the oestrous cycle and on days 7, 15 and 21 of pregnancy to study the localization of flt- 1 and KDR in corpora lutea. Six ovaries from three animals were used on each day. Ovaries were fixed in Bouin's solution and embedded in paraffin wax. Paraffin wax-embedded ovaries were cut into sections $(4 \mu \mathrm{m}$ in thickness). The tissue sections were deparaffinized in xylene and dehydrated in a graded series of ethanol. Immunohistochemistry for flt-1 was performed by a peroxidase-anti-peroxidase method (DAKO PAP kit; DAKO Japan Co. Ltd, Tokyo) using rabbit anti-human flt-1 polyclonal antibodies (C-17, sc-316; Santa Cruz Biotechnology, Santa Cruz, CA), which react specifically with rat flt- 1 . After inhibition of endogenous peroxidase activity with $0.3 \%(\mathrm{v} / \mathrm{v}) \mathrm{H}_{2} \mathrm{O}_{2}$ for $50 \mathrm{~min}$, the sections were incubated with $10 \%(\mathrm{v} / \mathrm{v})$ normal swine serum for $10 \mathrm{~min}$ at room temperature to avoid non-specific binding. The sections were incubated with primary antibody at a dilution of $1: 50$ in PBS-BSA (1\% w/v) overnight at $4^{\circ} \mathrm{C}$. After three washes with PBS for $5 \mathrm{~min}$ each, the sections were incubated with swine anti-rabbit immunoglobulin for $30 \mathrm{~min}$ at room temperature, washed three times with PBS for 5 min each, and reacted with rabbit-PAP for $40 \mathrm{~min}$ at room temperature. Immunohistochemistry for KDR and for CD34, a marker of vascular endothelial cells, was performed with a streptavidinbiotin-peroxidase complex method (SAB-PO kit; Nichirei Co. Ltd, Tokyo) using mouse anti-KDR monoclonal antibodies (A-3, sc-6251; Santa Cruz Biotechnology) and mouse anti-CD34 monoclonal antibodies (Santa Cruz Biotechnology), respectively. After inhibition of endogenous peroxidase activity with $0.3 \%(\mathrm{v} / \mathrm{v}) \mathrm{H}_{2} \mathrm{O}_{2}$ for $50 \mathrm{~min}$, the sections were incubated with $10 \%(\mathrm{v} / \mathrm{v})$ normal rabbit serum for $10 \mathrm{~min}$ at room temperature to avoid non-specific binding. The sections were incubated with the primary antibodies at a dilution of $1: 50$ in PBS-BSA $(1 \% \mathrm{w} / \mathrm{v})$ overnight at $4^{\circ} \mathrm{C}$. After three washes with PBS for $5 \mathrm{~min}$ each, the sections were incubated with biotinylated rabbit anti-mouse immunoglobulin for $10 \mathrm{~min}$ at room temperature, washed three times with PBS for 5 min each, and reacted with peroxidase-conjugated streptavidin for $5 \mathrm{~min}$ at room temperature. Peroxidase activity was visualized by incubating the sections with 3,3'-diaminobenzidine-4- $\mathrm{HCl}$ (Nacalai Tesque Co. Ltd, Tokyo) in 0.05 mol Tris-HCl buffer $\mathrm{I}^{-1}\left(\mathrm{pH}\right.$ 7.6) containing $0.01 \%(\mathrm{v} / \mathrm{v}) \mathrm{H}_{2} \mathrm{O}_{2}$ for 2 min. For controls, sections were incubated with normal rabbit serum for flt-1, or normal mouse serum for KDR and CD34, or the anti-flt- 1 antibody was pre-absorbed with an excess of flt-1 blocking peptide (sc-316p; Santa Cruz Biotechnology) overnight at $4^{\circ} \mathrm{C}$. Counterstaining was performed with Meyer's haematoxylin.

\section{Experiments}

A well-characterized oestradiol-treated hypophysectomized and hysterectomized pregnant rat model was used to study the involvement of oestradiol in flt- 1 and KDR expression in the corpus luteum during mid-pregnancy in rats (Gibori and Keyes, 1978). Hypophysectomy and hysterectomy were performed on day 12 of pregnancy under ether anaesthesia. Hysterectomy was performed through an abdominal mid-line incision as reported by Kashida et al. (2001). Hypophysectomy was performed by the parapharyngeal approach as reported by Kato et al. (1988). Completeness of removal of the pituitary gland was assessed by the absence of the pituitary gland in the fossa at autopsy. Rats received a daily s.c. injection of either $100 \mu \mathrm{g}$ oestradiol (Sigma Chemical Co., St Louis, MO) dissolved in $0.2 \mathrm{ml}$ sesame oil or sesame oil (control) daily until the morning of day 15 of pregnancy. The ovaries were removed on day 15 of pregnancy and corpora lutea were dissected and cleaned of adhering tissue in a watch glass. Corpora lutea were weighed, frozen immediately in liquid nitrogen and stored at $-80^{\circ} \mathrm{C}$ until RNA isolation was performed. All of the corpora lutea from each animal were used for RNA isolation and subjected to mRNA analysis as a single sample. Serum samples were stored at $-20^{\circ} \mathrm{C}$ until oestradiol and progesterone assays were performed.

The aim of the second experiment was to study developmental changes in flt-1 and KDR expression in the corpus luteum throughout pregnancy. Corpora lutea were collected on days 3, 7, 9, 12, 15 and 21 of pregnancy and stored at $-80^{\circ} \mathrm{C}$ until RNA isolation was performed. All of the corpora lutea from each animal were used for RNA isolation and subjected to mRNA analysis as a single sample.

\section{Reverse transcription-polymerase chain reaction (RT-PCR)}

Total RNA was isolated from corpora lutea with Isogen (Wako Pure Chemical Industries Ltd, Osaka) as directed by the manufacturer. For mRNA analysis, RT-PCR was performed as reported by Sugino et al. (1998a) with the oligo- 
nucleotide primers for flt-1 (5'-CATGGTCAGCTGCTGGGACACCGCG-3' and 5'-GACTCCCTGCATCACTAACAATAT-3') and for KDR (5'-TCAGATTACTTGCAGGGGACAGAGG-3' and 5'-GGATCACCACAGTTTTGTTCTTGTT-3') designed by Wang et al. (1998). Direct sequence analyses of the PCR products were performed for sequence verification. Two oligonucleotide primers (5'-CTGAAGGTCAAAGGGAATGTG-3' and 5'-GGACAGAGTCTTGATGATCTC-3') were used to amplify ribosomal protein L19 as an internal control (Chan et al., 1987). In brief, $3 \mu \mathrm{g}$ total RNA were reverse-transcribed at $42^{\circ} \mathrm{C}$ in a reaction mixture containing $1 \times$ PCR buffer, $2.5 \mathrm{mmol}$ deoxynucleotide triphosphates $\mathrm{I}^{-1}$ (Life Technologies Inc., Grand Island, NY), $5 \mu \mathrm{mol}$ random hexamer primer $\mathrm{I}^{-1}$ (Perkin-Elmer, Roche Molecular Systems Inc., Branchburg, NJ), $1.5 \mathrm{mmol} \mathrm{MgCl}_{2} \mathrm{I}^{-1}$ and $200 \mathrm{U}$ Moloney murine leukaemia virus reversetranscriptase (Perkin-Elmer). The reverse-transcribed product was divided into two tubes for flt- 1 or KDR primers and L19 primers, and PCR was performed. For PCR amplification, a mixture containing the oligonucleotide primers $(50 \mathrm{pmol})$, $\left[\alpha-{ }^{32} \mathrm{P}\right] \mathrm{dCTP} \quad\left(2 \mu \mathrm{Ci}\right.$ at $3000 \mathrm{Ci} \mathrm{mmol}^{-1}$; Amersham, Arlington Heights, IL) and Taq DNA polymerase (2.5 U; Perkin-Elmer) was added to each reaction. Amplification was carried out for 25 cycles each consisting of $94^{\circ} \mathrm{C}$ for $1 \mathrm{~min}, 62^{\circ} \mathrm{C}$ for $1 \mathrm{~min}$ and $72^{\circ} \mathrm{C}$ for $2 \mathrm{~min}$ for each set of flt-1 and L19, and KDR and L19, followed by 10 min final extension at $72^{\circ} \mathrm{C}$ in a program temperature control system PC-800 (ASTEC, Fukuoka). The predicted sizes of the PCR products were $400 \mathrm{bp}$ for flt-1, $300 \mathrm{bp}$ for KDR and $194 \mathrm{bp}$ for L19. A linear curve was plotted using number of cycles of amplification versus densitometric values of the PCR products, measured with a BAS 2000 (Fuji Photo Film Co., Tokyo). The optimal number of cycles for amplification that fits within the linear range was chosen for each set of primers for VEGF and L19 (data not shown). Reaction products were subjected to electrophoresis on an $8 \%$ $(\mathrm{w} / \mathrm{v})$ polyacrylamide non-denaturing gel. After autoradiography, band intensities were analysed using a bioimaging analyser BAS2000. For quantification, the densities of flt- 1 and KDR were normalized to that of the internal control L19.

\section{Hormone assay}

Serum progesterone and oestradiol concentrations were determined by specific radioimmunoassay as described previously (Kato et al., 1982; Sugino et al., 1991). The sensitivities of the assay were 100 pg per tube for the progesterone assay and $2.7 \mathrm{pg}$ per tube for the oestradiol assay. The intra- and interassay coefficients of variation were 7.0 and $14.4 \%$, respectively, for the progesterone assay, and 10.0 and $10.4 \%$, respectively, for the oestradiol assay.

\section{Statistical analysis}

Data were analysed by ANOVA and Duncan's new multiple range test. Differences were considered significant at $P<0.05$.

\section{Results}

Immunostaining for flt-1, KDR and CD34 in rat ovaries is shown (Fig. 1). Immunoreactivity to flt-1 and KDR was observed in luteal cells and in vascular endothelial cells on day 15 of pregnancy (flt-1: Fig. 1a,c,f; KDR: Fig. 1b,d,g; and CD34: Fig. 1e,h). In interstitial blood vessels, flt-1 and KDR immunoreactivities were also observed in vascular smooth muscle cells (Fig. 1f,g). Immunostaining intensity was strong in luteal cells compared with that in endothelial cells. These patterns of staining were similar in the corpus luteum on days 7,15 and 21 of pregnancy (data not shown). flt-1 immunostaining at oestrus and KDR immunostaining at dioestrus are shown (Fig. 1i,j). Compared with pregnant rats, flt-1 and KDR immunoreactivities were weak in luteal cells and vascular endothelial cells throughout the oestrous cycle. No flt-1 immunoreactivity was observed in the ovary on day 15 of pregnancy after pre-absorption of the anti-flt-1 antibody with an excess of flt-1 blocking peptide (Fig. $1 \mathrm{k}$ ). No KDR immunoreactivity was observed in the control section (Fig. 1l).

The well-characterized oestradiol-treated hypophysectomized and hysterectomized pregnant rat model was used to study the involvement of oestradiol on flt- 1 and KDR expression in the corpus luteum during mid-pregnancy in rats. In this model, hypophysectomy-hysterectomy decreased the mass of corpora lutea and serum progesterone concentrations markedly, whereas oestradiol treatment significantly $(P<0.01)$ reversed the inhibitory effects of hypophysectomy-hysterectomy, although serum oestradiol concentrations were very high (Table 1). flt-1 mRNA content in the corpus luteum was decreased significantly $(P<0.01)$ by hypophysectomy-hysterectomy, and this inhibitory effect was reversed completely by treatment with oestradiol (Fig. 2a). KDR mRNA content was also decreased significantly $(P<0.01)$ by hypophysectomy-hysterectomy, and this inhibitory effect was reversed significantly $(P<0.01)$ by the treatment with oestradiol (Fig. 2b). Changes in flt-1 and KDR mRNA contents in the corpus luteum throughout pregnancy were also examined. flt- 1 and KDR mRNA contents in the corpus luteum were constant until day 15 of pregnancy but decreased significantly on day 21 of pregnancy $(P<0.01)$ (Fig. 3).

\section{Discussion}

The results of the present study demonstrate that VEGF receptors, flt- 1 and KDR, are localized in luteal cells in addition to vascular endothelial cells. This finding is consistent with recent reports showing that flt- 1 and KDR are expressed in luteal cells of human corpora lutea (Otani et al., 1999; Sugino et al., 2000a). The results of the present study also indicate that flt-1 and KDR expression are increased in corpora lutea of pregnancy and are upregulated by oestradiol in the corpus luteum during midpregnancy. Kashida et al. (2001) reported that oestradiol activates angiogenesis and vascular permeability via VEGF 

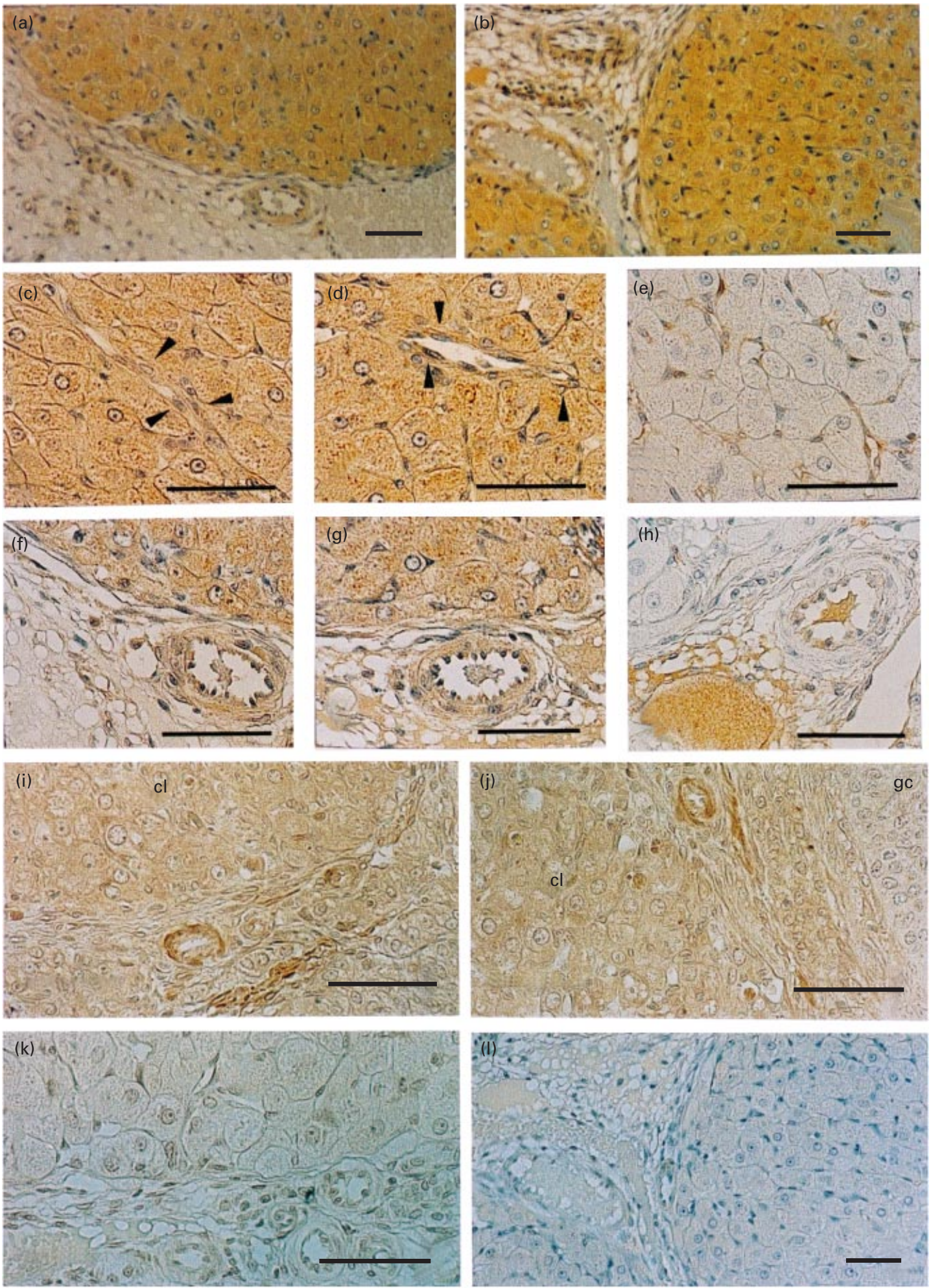

Fig. 1. Immunohistochemical staining for fms-like tyrosine kinase (flt-1), kinase insert domain-containing region (KDR) and CD34 in rat corpus luteum. (a) flt-1 and (b) KDR immunoreactivities were observed in luteal cells and interstitial blood vessels in the ovary on day 15 of pregnancy. At a higher magnification, (c) flt- 1 and (d) KDR immunoreactivities were observed in the cytoplasm of luteal cells and in vascular endothelial cells indicated by arrowheads in the corpus luteum. In interstitial blood vessels, (f) flt-1 and (g) KDR immunoreactivities were observed in endothelial cells and smooth muscle cells. CD34 immunoreactivities were localized in vascular endothelial cells (e,h). During the oestrous cycle, (i) flt-1 and (j) KDR immunoreactivities were faint in luteal cells 
Table 1. Mass of the corpus luteum, and serum progesterone and oestradiol concentrations in hypophysectomized-hysterectomized rats treated with or without oestradiol

\begin{tabular}{lcccc}
\hline Treatment & $n$ & $\begin{array}{c}\text { Mass of corpus } \\
\text { luteum }(\mathrm{mg})\end{array}$ & $\begin{array}{c}\text { Serum progesterone } \\
\left(\mathrm{ng} \mathrm{ml} l^{-1}\right)\end{array}$ & $\begin{array}{c}\text { Serum oestradiol } \\
\left(\mathrm{pg} \mathrm{ml^{-1 }}\right)\end{array}$ \\
\hline Control (day 15 of pregnancy) & 5 & $4.1 \pm 0.1$ & $132.8 \pm 9.1$ & $66.4 \pm 7.4$ \\
Hypophysectomy-hysterectomy + oil & 8 & $2.5 \pm 0.1^{\mathrm{a}}$ & $22.5 \pm 1.2^{\mathrm{a}}$ & $24.4 \pm 4.1$ \\
Hypophysectomy-hysterectomy + 100 $\mu$ g oestradiol & 7 & $3.9 \pm 0.1$ & $94.6 \pm 6.1^{\mathrm{b}}$ & $2244 \pm 489^{\mathrm{b}}$
\end{tabular}

Control: intact rats on day 15 of pregnancy.

Hypophysectomy-hysterectomy were performed on day 12 of pregnancy and oestradiol or sesame oil (control) was administered once a day until day 15 of pregnancy.

Values are mean \pm SEM.

a $P<0.01$ versus day 15 control or oestradiol-treated rats. ${ }^{\text {b }} P<0.01$ versus day 15 control.
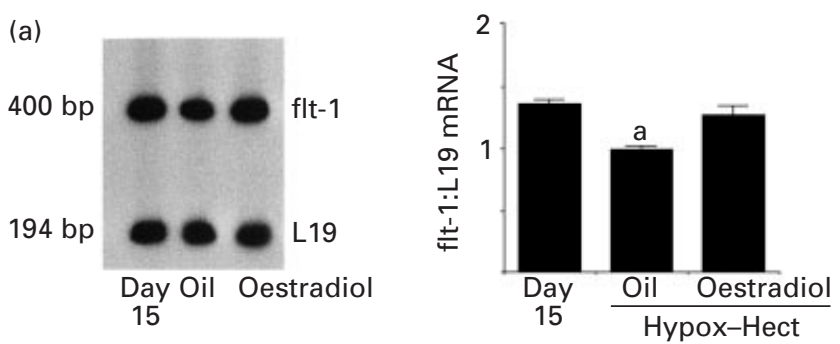

(b)
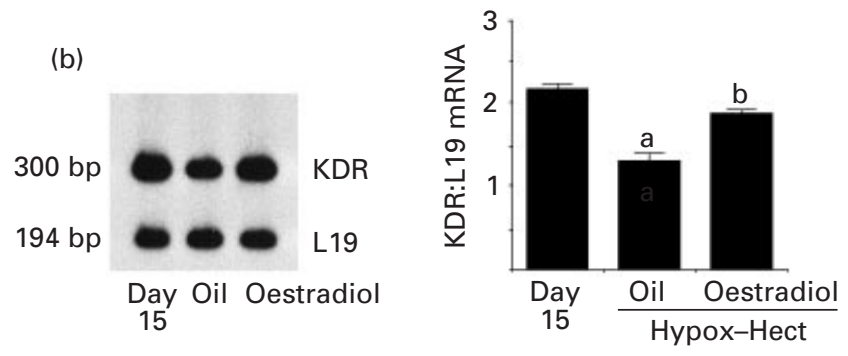

Fig. 2. Effects of oestradiol on mRNA content of (a) fms-like tyrosine kinase (flt- 1 ) and (b) kinase insert domain-containing region (KDR) in the corpus luteum during mid-pregnancy. Hypophysectomy and hysterectomy (Hypox-Hect) were performed on day 12 of pregnancy and oestradiol $(100 \mu \mathrm{g}, n=7)$ or sesame oil $(n=8)$ was injected daily until day 15 of pregnancy. Intact rats on day 15 of pregnancy $(n=5)$ were used as a control. The flt- 1 and KDR mRNA contents in the corpus luteum were determined by RT-PCR. The intensity of the signals of flt- 1 or KDR was normalized to that of the internal control L19. The quantification data (the ratio of flt-1 or KDR to L19) represent the mean \pm SEM. ${ }^{\text {a }} P<0.01$ versus day 15 and oestradiol. ${ }^{\mathrm{b}} \mathrm{P}<0.05$ versus day 15 .

in rat corpora lutea and contributes to the increases in both the size of the corpus luteum and production of progesterone during mid-pregnancy. The results of the present study indicate that oestradiol can activate VEGF and
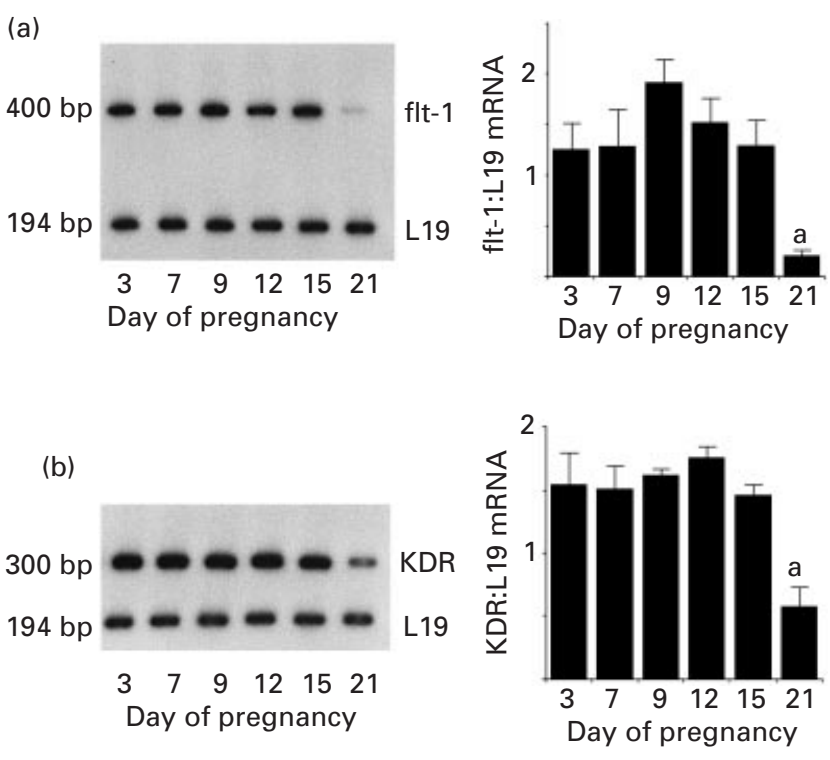

Fig. 3. Developmental changes in content of (a) fms-like tyrosine kinase (flt-1) and (b) kinase insert domain-containing region (KDR) mRNA in the corpus luteum during pregnancy. Corpora lutea were obtained on days $3(n=3), 7(n=3), 9(n=4), 12(n=5), 15(n=5)$ and $21(n=5)$ of pregnancy. Total RNA was isolated and subjected to RT-PCR. The quantification data (the ratio of flt-1 or KDR to L19) represent the mean \pm SEM. ${ }^{\text {a }} P<0.01$ versus the other days.

its receptor system in rat corpora lutea during midpregnancy. This finding is in good agreement with the knowledge that gonadotrophic hormones stimulate the VEGF system, which contributes to the development of corpora lutea (Otani et al., 1999; Berisha et al., 2000; Sugino et al., 2000a; Fraser and Lunn, 2001). In the present study, flt-1 and KDR were also localized in vascular smooth

(cl) compared with those in interstitial blood vessels. No KDR immunoreactivity was observed in granulosa cells (labelled 'gc'). (k) No flt-1 immunoreactivity was observed in the ovary on day 15 of pregnancy after preabsorption of the anti-flt- 1 antibody with an excess of flt-1 blocking peptide. (I) No KDR immunoreactivity was observed in the control section. Scale bars represent $50 \mu \mathrm{m}$. 
muscle cells. As Brown et al. (1997) reported that uterine smooth muscle cells express flt- 1 and KDR and proliferate in response to VEGF, it is possible that the VEGF system may be involved in the proliferation of vascular smooth muscle cells.

The present study raises the possibility that VEGF may exert a paracrine-autocrine role in regulation of luteal function in rats, as VEGF receptors are expressed in luteal cells. This possibility has also been suggested for human corpora lutea (Otani et al., 1999; Sugino et al., 2000a). Expression of VEGF receptors has been noted in a variety of non-endothelial cells (Ergün et al., 1997; Wen et al., 1998; Krüssel et al., 1999; Möller et al., 2001). In addition, flt-1 and KDR can act as functional receptors for VEGF in nonendothelial cells (Barleon et al., 1996; Clauss et al., 1996; Ahmed et al., 1997; Brown et al., 1997; Athanassiades et al., 1998). It is of special interest to note that VEGF can act as a survival factor and inhibit apoptosis (Spyridopoulos et al., 1997; Gerber et al., 1998). Apoptosis may play an important role in the determination of the lifespan of luteal cells (Juengel et al., 1993; Sugino et al., 1996, 1999a, 2000b; McCormack et al., 1998; Roughton et al., 1999). Sugino et al. (2000a) reported that expression of flt-1 and KDR in human luteal cells was high during the mid-luteal phase and in early pregnancy. In addition, in the present study, the constant high expression of flt-1 and KDR until mid-pregnancy and upregulation of flt-1 and KDR by oestradiol may indicate that flt- 1 and KDR are involved in the regulation of luteal lifespan. This possibility may be supported by the finding that flt- 1 and KDR mRNA contents were low in the corpus luteum on day 21 of pregnancy, when it is undergoing luteolysis. This low expression of VEGF receptor mRNA may be due to the decrease in the stimulatory effect of oestradiol or to a cytokine such as tumour necrosis factor $\alpha(\mathrm{TNF}-\alpha)$, the concentration of which increases in the corpus luteum during regression (Bagavandoss et al., 1990; Shaw and Britt, 1995) and can inhibit expression of VEGF receptor (Patterson et al., 1996). Although there appears to be a discrepancy between low mRNA content and intense immunostaining on day 21 of pregnancy, this may be due to the different sensitivities of RT-PCR and immunohistochemistry.

As the content of VEGF receptor mRNA was increased in the corpus luteum by oestradiol during mid-pregnancy, the change in VEGF receptor expression in the corpus luteum throughout pregnancy was examined. However, until day 15 of pregnancy, no correlation was found between expression of VEGF receptor mRNA and the developmental changes that occur in the corpus luteum. It is unclear why the mRNA contents of flt- 1 and KDR in the corpus luteum were constant until day 15 of pregnancy although oestradiol concentrations in the corpus luteum increase in the second half of pregnancy (Taya and Greenwald, 1981) and expression of flt- 1 and KDR mRNA is upregulated by oestradiol. It is possible that other factors in addition to oestradiol are involved in the regulation of expression of flt- 1 and KDR mRNAs in the corpus luteum during mid- pregnancy. In fact, the effects demonstrated by the experimental animal model or the in vitro model are not always consistent with the developmental changes that occur during pregnancy, which is indicative of the involvement of several factors (Parmer et al., 1991; Sugino et al., 1998b, 1999b; Telleria et al., 1998).

In conclusion, the results of the present study demonstrate that VEGF receptors, flt- 1 and KDR, are expressed in luteal cells in addition to vascular endothelial cells and are upregulated by oestradiol in the corpus luteum during mid-pregnancy. These results indicate that flt- 1 and KDR may play a role in the regulation of luteal function.

This work was supported in part by a grant from the UBE Foundation and Grant-in-Aid for Scientific Research (11671623 and 13671721) from the Ministry of Education, Science, and Culture, Japan. N. Sugino and S. Kashida contributed equally to this work.

\section{References}

Ahmed A, Dunk C, Kniss D and Wilkes M (1997) Role of VEGF receptor-1 (Flt-1) in mediating calcium-dependent nitric oxide release and limiting DNA synthesis in human trophoblast cells Laboratory Investigation $\mathbf{7 6}$ 779-791

Athanassiades A, Hamilton GS and Lala PK (1998) Vascular endothelial growth factor stimulates proliferation but not migration or invasiveness in human extravillous trophoblast Biology of Reproduction 59 643-654

Bagavandoss P, Wiggins RC, Kunkel SL, Remick DG and Keyes PL (1990) Tumor necrosis factor production and accumulation of inflammatory cells in the corpus luteum of pseudopregnancy and pregnancy in rabbits Biology of Reproduction 42 367-376

Barleon B, Sozzani S, Zhou D, Weich HA, Mantovani A and Marme D (1996) Migration of human monocytes in response to vascular endothelial growth factor (VEGF) is mediated via the VEGF receptor flt-1 Blood 87 3336-3343

Berisha B, Schams D, Kosmann M, Amselgruber W and Einspanier R (2000) Expression and tissue concentration of vascular endothelial growth factor, its receptors, and localization in the bovine corpus luteum during estrous cycle and pregnancy Biology of Reproduction 63 1106-1114

Brown LF, Detmar M, Tognazzi K, Abu-Jawdeh G and Iruela-Arispe ML (1997) Uterine smooth muscle cells express functional receptors (flt-1 and KDR) for vascular permeability factor/vascular endothelial growth factor Laboratory Investigation 76 245-255

Bruce NW, Meyer GT and Dharmarajan AM (1984) Rate of blood flow and growth of the corpora lutea of pregnancy and of previous cycles throughout pregnancy in the rat Journal of Reproduction and Fertility 71 445-452

Chan YL, Lin A, McNally J, Pelleg D, Meyuhas O and Wool I (1987) The primary structure of rat ribosomal protein L19 Journal of Biological Chemistry 193 265-275

Clauss M, Weich H, Breier G, Knies U, Röck W, Waltenberger J and Risau W (1996) The vascular endothelial growth factor receptor Flt-1 mediates biological activities Journal of Biological Chemistry 27117 629-17 634

Ergün S, Kilic N, Fiedler W and Mukhopadhyay AK (1997) Vascular endothelial growth factor and its receptors in normal human testicular tissue Molecular Cellular Endocrinology 131 9-20

Ferrara N and Davis-Smyth T (1997) The biology of vascular endothelial growth factor Endocrine Reviews 18 4-25

Ferrara N, Chen H, Davis-Smyth T, Gerber HP, Nguyen TN, Peers D, Chisholm V, Hillan KJ and Schwall RH (1998) Vascular endothelial growth factor is essential for corpus luteum angiogenesis Nature Medicine 4 336-340

Fraser HM and Lunn SF (2001) Regulation and manipulation of angiogenesis in the primate corpus luteum Reproduction 121 355-362

Fraser HM, Dickson SE, Lunn SF, Wulff C, Morris KD, Carrall VA and 
Bicknell R (2000) Suppression of luteal angiogenesis in the primate after neutralization of vascular endothelial growth factor Endocrinology 141 995-1000

Gerber HP, Dixit V and Ferrara N (1998) Vascular endothelial growth factor induces expression of the antiapoptotic proteins Bcl-2 and A1 in vascular endothelial cells Journal of Biological Chemistry 27313 313-13 316

Gibori G (1993) The corpus luteum of pregnancy. In The Ovary pp 261-317 Eds EY Adashi and PCK Leung. Raven Press, New York

Gibori G and Keyes PL (1978) Role of intraluteal estrogen in the regulation of the rat corpus luteum during pregnancy Endocrinology 102 $1176-1182$

Juengel JL, Garverick HA, Johnson AL, Youngquist RS and Smith MF (1993) Apoptosis during luteal regression in cattle Endocrinology 132 249-254

Kashida S, Sugino N, Takiguchi S, Karube A, Takayama H, Yamagata Y, Nakamura Y and Kato H (2001) Regulation and role of vascular endothelial growth factor in the corpus luteum during mid-pregnancy in rats Biology of Reproduction 64 317-323

Kato H, Ueda K, Tsutsui H, Miyauchi F and Torigoe T (1982) Role of the non-gravid part of the uterus in the regulation of corpus luteum function in pregnant rats Endocrinology 111 2020-2024

Kato H, Nanjo K, Numa F, Nakamura Y, Ueda K, Inoguchi H and Torigoe T (1988) Inhibitory effects of adrenocorticotrophin or corticosterone on progesterone secretion during mid-pregnancy in rats Journal of Reproduction and Fertility 83 867-872

Koos RD (1995) Increased expression of vascular endothelial growth/ permeability factor in the rat ovary following an ovulatory gonadotropin stimulus Biology of Reproduction 52 1426-1435

Krüssel JS, Casan EM, Raga F, Hirchenhain J, Wen Y, Huang HY, Biefeld P and Polan ML (1999) Expression of mRNA for vascular endothelial growth factor transmembraneous receptors Flt-1 and KDR, and the soluble receptor sflt in cycling human endometrium Molecular Human Reproduction 5 452-458

McCormack JT, Friederichs MG, Limback SD and Greenwald GS (1998) Apoptosis during spontaneous luteolysis in the cyclic golden hamster: biochemical and morphological evidence Biology of Reproduction $\mathbf{5 8}$ 255-260

Möller B, Rasmussen C, Lindblom B and Olovsson M (2001) Expression of the angiogenic growth factors VEGF, FGF-2, EGF and their receptors in normal human endometrium during the menstrual cycle Molecular Human Reproduction 7 65-72

Otani N, Minami S, Yamoto M, Shikone T, Otani H, Nishiyama R, Otani T and Nakano R (1999) The vascular endothelial growth factor/fms-like tyrosine kinase system in human ovary during the menstrual cycle and early pregnancy Journal of Clinical Endocrinology and Metabolism $\mathbf{8 4}$ 3845-3851

Parmer TG, Roberts CT, LeRoth D, Adashi EY, Khan I, Solan N, Nelson S, Zilberstein M and Gibori G (1991) Expression, action, and steroidal regulation of insulin-like growth factor-I (IGF-I) and IGF-I receptor in the rat corpus luteum: their differential role in the two cell populations forming the corpus luteum Endocrinology 129 2924-2932

Patterson C, Perrella MA, Endege WO, Yoshizumi M, Lee ME and Haber E (1996) Downregulation of vascular endothelial growth factor receptors by tumor necrosis factor-a in cultured human vascular endothelial cells Journal of Clinical Investigation 98 490-496

Phillps HS, Hains J, Leung DW and Ferrara N (1990) Vascular endothelial growth factor is expressed in rat corpus luteum Endocrinology 127 965-967

Roughton SA, Lareu RR, Bittles AH and Dharmarajan AM (1999) Fas and Fas ligand messenger ribonucleic acid and protein expression in the rat corpus luteum during apoptosis-mediated luteolysis Biology of Reproduction 60 797-804
Shaw C and Britt J (1995) Concentrations of tumor necrosis factor- $\alpha$ and progesterone within the bovine corpus luteum sampled by continuous flow microdialysis during luteolysis in vivo. Biology of Reproduction $\mathbf{5 3}$ $847-854$

Spyridopoulos I, Brogi E, Kearney M, Sullivan AB, Cetrulo C, Isner JM and Losordo DW (1997) Vascular endothelial growth factor inhibits endothelial cell apoptosis induced by tumor necrosis factor- $\alpha$ : balance between growth and death signals Journal of Molecular Cellular Cardiology 29 1321-1330

Sugino N, Tamura H, Nakamura Y, Ueda K and Kato H (1991) Different mechanisms for the inhibition of progesterone secretion by ACTH and corticosterone in pregnant rats Journal of Endocrinology 129 405-410

Sugino N, Takiguchi S, Ono M et al. (1996) Nitric oxide concentrations in the follicular fluid and apoptosis of granulosa cells in human follicles Human Reproduction 11 2484-2487

Sugino N, Zilberstein M, Srivastava RK, Telleria CM, Nelson SE, Risk M, Chou JY and Gibori G (1998a) Establishment and characterization of a simian virus 40-transformed temperature-sensitive rat luteal cell line Endocrinology 139 1936-1942

Sugino N, Telleria CM and Gibori G (1998b) Differential regulation of copper-zinc superoxide dismutase and manganese superoxide dismutase in the rat corpus luteum: induction of manganese superoxide dismutase messenger ribonucleic acid by inflammatory cytokines Biology of Reproduction $\mathbf{5 9} 208-215$

Sugino N, Takiguchi S, Kashida S, Takayama H, Yamagata Y, Nakamura Y and Kato H (1999a) Suppression of intracellular superoxide dismutase activity by antisense oligonucleotides causes inhibition of progesterone production by rat luteal cells Biology of Reproduction 61 1133-1138

Sugino N, Telleria CM, Tessier C and Gibori G (1999b) Regulation and role of the insulin-like growth factor I system in rat luteal cells Journal of Reproduction and Fertility 115 349-355

Sugino N, Kashida S, Takiguchi S, Karube A and Kato H (2000a) Expression of vascular endothelial growth factor and its receptors in the human corpus luteum during the menstrual cycle and in early pregnancy Journal of Clinical Endocrinology and Metabolism 85 3919-3924

Sugino N, Suzuki T, Kashida S, Karube A, Takiguchi S and Kato H (2000b) Expression of $\mathrm{BCL}-2$ and $\mathrm{Bax}$ in the human corpus luteum during the menstrual cycle and in early pregnancy: regulation by human chorionic gonadotropin Journal of Clinical Endocrinology and Metabolism 85 4379-4386

Tamura H and Greenwald GS (1987) Angiogenesis and its hormonal control in the corpus luteum of the pregnant rat Biology of Reproduction 36 1149-1154

Taya K and Greenwald GS (1981) In vivo and in vitro ovarian steroidogenesis in the pregnant rat Biology of Reproduction 25 683-692

Telleria CM, Zhong L, Deb S, Srivastava RK, Park KS, Sugino N, Park Sarge OK and Gibori G (1998) Differential expression of the estrogen receptor $\alpha$ and $\beta$ in the rat corpus luteum of pregnancy: regulation by prolactin and placental lactogens Endocrinology 139 2432-2442

Wang JF, Milosveski V, Schramek C, Fong GH, Becks GP and Hill DJ (1998) Presence and possible role of vascular endothelial growth factor in thyroid cell growth and function Journal of Endocrinology 157 5-12

Wen Y, Edelman JL, Kang T, Zeng N and Sachs G (1998) Two functional forms of vascular endothelial growth factor receptor-2/Flk-1 mRNA are expressed in normal rat retina Journal of Biological Chemistry 273 2090-2097

Received 5 March 2001.

First decision 30 April 2001.

Final version received 19 July 2001

Accepted 30 July 2001. 